\title{
The Ethical Value of the Inhumanity in Art \\ A Levinasian Reading
}

\author{
Aisha Ryannon Pagnes \\ ryannon.aisha@gmail.com
}

\begin{abstract}
Reality and its Shadow, a brief yet powerful essay written in 1948, is the only text where Emmanuel Levinas (1906-1995) deals solely with the ontology of art. Already in this early text, we can see how his understanding that ethics is the ground of philosophy drives his discussion. The nature of art is therefore treated in relation to what it does, ethically, to the subject, the maker, and the viewer. Art is the "inhumanity" and "inversion" of ethics. Only philosophical criticism reintegrates its "inhumanity" in the ethical relation. The strength of Levinas's philosophy issues from a pre-cognitive commitment to the "other", epitomised in the "face to face" relation. Any philosophy emphasising the primacy of the subject over and above the "other" crumbles under his reading. Yet this same strength implies that those domains where the "face to face" relation is obscured lead to irresponsibility. One such domain is art. In this essay I argue that by applying his mature work to the criticism he advances in Reality and its Shadow we can find ethical value in art in virtue of its "inhumanity" and "inversion". That is, we can agree with Levinas that art leads to irresponsibility, and yet ascribe to it positive ethical value in Levinas's own terms. This can help concretise the tension between the ethical and unethical aspects of art within a Levinasian framework.
\end{abstract}

Keywords: Levinas, Other, Face to Face, Art. 


\title{
The Ethical Value of the Inhumanity in Art \\ A Levinasian Reading
}

\author{
Aisha Ryannon Pagnes \\ ryannon.aisha@gmail.com
}

\section{Introduction}

Emmanuel Levinas's ethics is not a constructive one. Its power issues from the efforts to describe a pre-cognitive and continuous commitment to the "other". The "other" is undefinable, destabilises our attempts to fix meaning, and as such compels us to respond. This means that any philosophy attempting to define the "other", prescribe principles of behaviour, or emphasise the primacy of the subject, crumbles under his reading. Levinas wants to show how we are radically and always already committed to the "other": an intersubjective responsibility made manifest especially in language. To respond is to already confirm the fact of our pull toward the "other", which we experience most readily in the "face to face" relation. This is a key phrase. To be "face to face" is to meet an other as "other" and be met as "other". The "face" is both the being with which a person coincides and its "caricature". It is both an image and a form through which the indefinability, or as Levinas says, "infinity" of the "other" irrupts. In the context of Western philosophy, Levinas' radical move is to demonstrate, by way of phenomenological description, how the significance of this everyday encounter is not only the source of ethics, but lies at the ground of human experience, and consequently at the ground of philosophy.

Naturally, the primacy of ethics in Levinas' thought, specifically as intersubjective responsibility, determines his criticism of philosophies and practices that detract from or impede such responsibility. Even before the publication of his two major works Totality and Infinity (1961) and Otherwise than Being, or Beyond Essence (1974), the primacy of ethics in Levinas' thought is already present. From the onset it is clear how in Reality and its Shadow (henceforth RS), the only essay dealing in its entirety with the ontology of art, is in effect guided by a criticism of the ethical dimension - or lack thereof - in 
art. In this brief yet powerful essay written in 1948, Levinas argues that art is fundamentally irresponsible. It traps beings in their fate, it empties them of being by representing them, and obscures the frankness of discourse by transforming the "revelation" of being into the plasticity of "myth"; terms that will becomes clear as we proceed.

Levinas builds a valid line of argument by leveraging the conceptual division between criticism and art proper. Criticism reintegrates the inhumanity and inversion of art, whereas art proper disengages from ethical responsibility. Although the division is mainly conceptual, in fact art is inseparable from ethics in the critical urge it prompts, it may mislead us to view Levinas as hostile toward art, as Richard Cohen rightly criticises $^{1}$. To extremise: if we agree with what is essentially a misinterpretation of Levinas's argument, we run the risk of demoting the value of art to mere entertainment or pleasure; if we disagree, we run the counter risk of valorising art irrespectively of ethical responsibility, also a form of trivialisation. Although Levinas considers art as the "inverse" of ethics, this does not mean that art is antithetical to ethics. The urge to criticism that art inspires or provokes, is already a reversal of its "inversion". The present thesis maintains that by applying his mature work to the criticism he advances in Reality and its Shadow we can find ethical value in art in virtue of its "inhumanity" and "inversion". That is, we can agree with Levinas that art leads to irresponsibility, and yet ascribe to it positive ethical value in Levinas's own terms. This can help concretise the tension between the ethical and unethical aspects of art within a Levinasian framework. First however, we must delimit our understanding of art.

Art deals with objects and characters, be they real, fictive, temporal or plastic; it separates these from daily life in virtue of the work's completeness, and promotes an attitude disengaged from ethical responsibility: to enjoy art is to renounce «the effort of science, philosophy and action» ${ }^{2}$. Art can lull us into a state of passive contemplation, which is not only irresponsible, but at times as shameful as «feasting during a plague» ${ }^{3}$. And since his intent is in showing how either the "making" or "experiencing" of the

\footnotetext{
${ }^{1}$ R. Cohen, Levinas on Art and Aestheticism: Getting 'Reality and Its Shadow' Right, in "Levinas Studies”, XI, 2016, pp. 149-194.

${ }^{2}$ E. Levinas, Reality and its Shadow (1948), transl. by A. Lingis, in E. Levinas, S. Hand (ed. by) The Levinas Reader: Emmanuel Levinas, Basil Blackwell, Oxford 1989, p. 141.

${ }^{3}$ Ivi, p. 142.
} 
work of art is irresponsible, it will suffice to clarify how this is the case without needing to treat either the making of or experiencing of art separately.

Secondly, although RS prefigures the development of his major works, we can still see how requirement of the "face to face" relation, already latent in his early pieces, inflects his understanding of art. Art, even when supported by theories affirming its function to be that of expression, speaks in a language categorically other from that of frank discourse. Only in discourse, which presupposes a first encounter, can the "face" of the "other" command responsibility from the self. This responsibility toward the "other" is for Levinas absent in the work of art, mostly due to the strong distinction he draws between art and criticism. «If art originally were neither language nor knowledge [...] criticism would be rehabilitated. It would represent the intervention of the understanding necessary for integrating the inhumanity and inversion of art into human life and into the mind ${ }^{4}$.

Thirdly, and as a last delimitation for this inquiry, we will refrain from using as entry strategies the two provisos problematising and reinstating criticism as the rehumanization of art, with which he opens and closes his discussion. Artists can speak and know, via manifestoes, speeches, public statements etc., but in so doing they become part of the consorting public engaged in discourse, a mode of being contiguous with his ethics whereby the use of language as a straightforward means of expression already presupposes one's responsibility toward the "other". Even if artists could not speak of their art, the inhumanity and inversion of art would only hold when «separated from the criticism that integrates the inhuman work of the artist into the human world» ${ }^{5}$. From this closing remark, it would seem that what is condemned is the enjoyment of art pure and simple: a silent, pacified state of contemplation that does not move beyond itself, a mere source of pleasure that disengages one from responsibility ${ }^{6}$.

These provisos then, provide the explicit condition for the reintegration of art into the domain of ethics: art ceases to be inhuman the moment it is brought back into the world of responsibility by philosophical exegesis and criticism. Philosophical exegesis and criticism speak frankly and openly, at least ideally, in order to make clear what art has obscured. In this regard, the operation of art on its object is conceived in stark contrast

\footnotetext{
${ }^{4}$ Ivi, p. 131.

${ }_{6}^{5}$ Ivi, p. 142.

${ }^{6}$ Explicitly expressed in RS, p. 141.
} 
to the Heideggerian thesis we find in the Origin of the Work of Art. Art is not the unconcealment of aspects of Being ${ }^{7}$. On the contrary, it is the obscuring of the being, it is "myth". For Levinas Art as myth is «at the same time untruth and source of philosophical truth ${ }^{8}$. By analogy, the poetic value of Hesiod's Theogony and Homer's epics, belonging to an altogether different order than that of truth and discourse, lies in its spurring Thales to speak of reality through the frankness of scientific and conceptual language. This formulaic evocation for the shorthanded birth of philosophy is at first glance reminiscent of Plato's view of art as "ancilla", a mere hand-maiden of philosophy in pursuing the "work of being" - which Levinas will come to develop as the relation with the infinite as "other" -. Yet it differs from it in that art is not devalued as a human practice whose justification is that of reinforcing philosophical insights through emotional appeal, but rather, is hand-maiden insofar as the violence it inflicts on reality urges one to criticism.

My objective then, is to ask whether this violence so understood can have positive ethical value in virtue of its "inhumanity" and its "inversion" of ethics, and if so, how. To do this, I will look in detail at what "inhumanity" and "inversion" mean. Section one looks at these terms and the operation art performs on its material, followed by considering the role time plays in this operation. Section two looks at how art's "inversion" of ethics leads to the "inhumanity" of the spectator: a mode of relating which is further clarified by Levinas's concept of "rhythm". Finally, in section three I reframe the need for art as the taming of the tension between an "allergic" and "nonallergic" movement toward the "other"; two modes of being advanced in Totality and Infinity (henceforth $\mathrm{TI})^{9}$ which can help ground the ambivalent ethical character of art.

\section{The inhuman inversion of the object into art}

The "inhumanity" of art is the obscuring of the "work of being" into "shadow". To understand this, we must look at the implications of art's most basic operation upon its

\footnotetext{
${ }^{7}$ M. Heidegger, The Origin of the Work of Art (1960), trans. by A. Hofstadter, in M. Heidegger, A. Hofstadter (ed. by) Poetry, Language, Thought, Perennial Library, New York 1975, p. 35.

${ }^{8}$ E. Levinas, Reality and its Shadow, cit., p. 142.

${ }^{9}$ E. Levinas, Totality and Infinity: An essay on exteriority (1961), transl. by A. Lingis, Martinus Nijhoff Publishers, Boston 1979.
} 
material. Art «consists in substituting for the object its image» ${ }^{10}:$ the image traps the object on the "hither side of time", the "meanwhile" (a concept clarified in the next section) and precludes it from its ability to speak. This substitution of the object for its image is the work of representation, where image is not intended as a pictorial twodimensional composition but the effect of translating the intercourse with reality into situations: Brancusi's Bird in Space - a sculptural abstraction of flight - is no less an image than is Poe's Raven - a poetic interpretation of suffering in beauty - .

Contrary to theories affirming representation to lead from the image to the object it represents, as though the image were a clear pane which one could see through to the object, Levinas insists on the duality of reality and representation. There is a distance between the object and the image of the object, and the relation between these two moments he calls resemblance. An image is functionally unlike a symbol, a sign or a word used in discourse. These latter force the presence of the object in its absence, whereas an image, through its presence «insists on [the] absence» ${ }^{11}$ of the object. Veering towards Plato's theory of mimesis, what is distinctive in Levinas is not a quantifiable distance between an object (or an ideal form) and its image - even those arts which seemingly do away with representation in sounding «pure music, writing pure words, and painting pure colour», do not in themselves «break through representation» $-{ }^{12}$, but rather the doubling up of reality. «A being is that which is, that which reveals itself in its truth, and, at the same time, it resembles itself, is its own image» $^{13}$; «thus a person bears on his face, alongside of its being with which he coincides, its own caricature» ${ }^{14}$. Resemblance is the simultaneity of a being with its image; although a resemblance is always an in-between space, in this case relating a living instance to its image, the movement of resemblance from being to image is asymmetrical. The "caricature" of the face does not lead back to the face with which being coincides; whereas «the face, still a thing among things, breaks through the form

\footnotetext{
${ }^{10}$ E. Levinas, Reality and its Shadow, cit., p. 132.

${ }^{11}$ Ivi, p. 136.

${ }^{12}$ Ivi, p. 134. This is so because Levinas couples sensation, noun root of aesthetics, with the «musicality» that every image engenders. A work of art does not have to represent a concrete or abstract object to substitute images for objects. It needs to image (as verb) reality by selecting, sectioning, arranging, completing.

${ }^{13}$ Ivi, p. 135

14 Ibid.
} 
that nevertheless delimits it» ${ }^{15}$, reveals its self through its "caricature". Representation then, is the vectorial culmination of the movement of resemblance, disengaging the image from its being and acquiring independent existence in virtue of its sensible aspects. It is in this sense that we cannot go from representation to the being it represents as we could with a symbol, the transparency of which does not transfix the viewer in its sensible qualities. Of the "sensible" we read that it «is being insofar as it resembles itself $[\ldots]$ it casts a shadow [...] a phantom essence which cannot be identified with the essence revealed in truth» ${ }^{16}$. It follows then, that if art's most basic operation is the substitution of being for its image, art deals with "shadows" and not reality.

Our cognitive grasp of objects does not in itself allow objects to "speak", and as we know from Totality and Infinity, Levinas's ethics stems strictly from the "face to face" relation: we cannot speak of a human face where it does not figure. The object as being cannot irrupt through its own "caricature" given that it lacks the "unforeseeable" character Levinas attributes to the face. Nor can we argue that the work of art can speak to us nonetheless provided the face in the "face to face" encounter is a metaphorical face $^{17}$, for even if this were the case, the work of art as object cannot "contest" the meaning we ascribe to it as the "other" can. And if the desiderata for Levinasian ethics are human faces and their "unforeseeable" character we cannot not hope to bear witness to the "other" in the work of art by appealing to art practices whose medium is the body in its "naked" authenticity, found for instance in early $20^{\text {th }}$ century experimental theatre and performance art. This is because their "unforeseeable" character takes them outside the domain of art proper, according at least to the understanding of art we established. If the artwork can speak it is no longer art and becomes "human", and if it is art, it is the "inversion" of being into image.

\footnotetext{
${ }^{15}$ E. Levinas, Totality and Infinity, cit., p. 198.

${ }^{16}$ E. Levinas, Reality and its Shadow, cit., p. 137.

${ }^{17}$ Creative adaptations of Levinasian ethics seem to do this precisely, hoping to retain the advantages of an existential intersubjective metaphysics - based on the irreducibility of the "other" - without weakening the import of metaphysical desire. This paper tries to refrain from such adaptation, which Levinas would not have agreed with, even though he recognised issues with restricting the scope of his ethics to the "face to face" encounter. See for instance B. J. Davy, An Other Face of Ethics in Levinas, in "Ethics and the Environment", XII/1, 2007, pp. 39-65 and H. McDonald, Aesthetics as first ethics: Levinas and the Alterity of Literary Discourse, in "Diacritics", XXXVIII/4, 2008, pp. 15-41.
} 


\subsection{Time and the artwork}

So far, we have seen that art cannot accommodate the "face to face" relation, which Levinas bases his ethics on. This is so because art's most basic operation is representation and because the art object cannot break through this representation as would a human face. Now we will look at what this representation entails for the being that is represented by considering the notion of the "meanwhile".

The "meanwhile" is the "hither side of time" that the artwork traps the representation of being in: the eternal duration of the interval. In the "meanwhile" a being is held back by its shadow. With a cluster of notions (image, allegory, idol, statue, plastic, myth) whose import underscores the ways in which the work of art qua image robs being from its temporality, Levinas draws a relation between the phenomenon of art and an existential anxiety which I now elaborate on. The "meanwhile" is the nature of liminal time as conceived in dying. Death is of the other, the self can only know dying: a moment infinitely protracted precisely for its inability to pass as the fulfilment of a future as new present. The "meanwhile", «inhuman and monstrous» ${ }^{18}$, runs parallel to the time of the living. Art is seen as the sublation of death in time, for the art work, in as much as its formal completeness endows it with a «constituted duration» ${ }^{19}$, removes from death the power to interrupt by situating representation, the image, beyond the temporal domain within which this is possible, the "hither side of time", the "meanwhile". This also means that the present cannot fulfil itself, cannot pass, lacks the character of evanescence. It is forward looking, but its ability to move beyond itself is denied, or rather, withdrawn from it, it is made "impotent". The anxiety the meanwhile provokes as a presentiment of the living's fate, is tempered by the duration of the artwork which is its completeness. This completeness is akin to a "death" as the trapping of an image on the hither side of time simultaneously «doubling the impulse of life» ${ }^{20}$ by birthing its shadow. Yet the act of representation, in its asymmetry, severs the shadow from its object and traps it in this constituted time, leading it beyond the time of a painting's life-span or a play's duration, to the "hither side": an eternal interval which

\footnotetext{
${ }^{18}$ E. Levinas, Reality and its Shadow, cit., p. 141.

${ }^{19}$ Ivi, p. 140.

${ }^{20}$ Ibid.
} 
the shadow of being cannot traverse, just as the self cannot traverse the interval in dying. It is a time that infinitely repeats, that precludes the semblance of being from fulfilling the possibility of its future, since the «life of an artwork does not go beyond the limit of an instant» ${ }^{21}$.

But whereas beings are able to "traverse" the "meanwhile", to fulfil the possibility of a future in a new present, the shadow of being is eternally imprisoned in this instant, its fate, from which it cannot escape. The shadow of art "aspires" to life insofar as it is the shadow of a living reality, but it is a mere "caricature of life", impotent in its fixity, in its completeness. This impossibility of fulfilling its potential future is the plastic character of the image, a plasticity that fixes shadows in closed-ended situations. The transformation of «time into images» ${ }^{22}$, their fixing them into situations which rhythmically enthrals, is "myth" as the «plasticity of a history»", namely, the selective procedure that arranges and composes the images of objects, events, and being into staticity. This is not to say that history is "myth" insofar as any historical event requires interpretation - which Levinas ascribes to the domain of philosophical discourse -, but that a mode of engaging with reality is via its plasticity, the relational character of which he sees as the "inverse" of ethical life. This is simply because in its fixity, a shadow cannot contest the totalising powers of the self. The self totalizes when it represents to itself the world of experience. This tendency toward totalisation is interrupted solely by the agency of the "other". A stereotype is as much a representation as is an art object. But whereas we can understand the power and danger of stereotypes in a political arena when confronted by the "other" that the stereotype represents, the nature of art is such that via its aesthetic dimension we can ignore the importance of criticism. An individual with only art objects at his disposal cannot engage with ethics, for these do not have the power to interrupt his totalising powers. And although art works, especially literary, can have moral import, they nonetheless allow us to enjoy our experience of them without ulterior call to action. Levinas's intent is that of exposing the dangers of art qua representation for ethics at the expense of experiential subtlety and complexity. What he is going up against is the position that ethics - as the metaphysical source of learning - can be subordinated to art.

\footnotetext{
${ }^{21}$ Ivi, p. 138.

${ }^{22}$ Ivi, p. 139.

23 Ibid.
} 


\section{The relation to the work of art as inversion leading to inhumanity}

In addition to the work of representation of art on the object, we have seen how representation prevents the represented being from interrupting the totalizing powers of the spectator, since the spectator as self relates to the image and not the object, or person: an "inversion" of the ethical relation. We now extend this thought and look at what kind of interaction this entails.

In fact, there is a second more prescient form of inhuman "inversion" that the artobject performs on our relation with reality. The permission we give to art-objects as images to have effect on us is «inverted into participation», "where commerce with reality is a rhythm» ${ }^{24}$. For Levinas, the ability to represent, is an extension of the power of the "I" to negate the alterity with which it is met by grasping or comprehending ${ }^{25}$, returning alterity to itself by its constant work of self-identification. But whereas the "grasping" of objects through labour and action necessarily assumes their existence in thought, the "rhythm" which accompanies representation transfixes the self in a liminal state between consciousness and unconsciousness where its ability to conceptualise is forestalled, much like the shadow is fixed in the liminal yet motionless time of the "meanwhile" it cannot cross. Objects are no longer assumed, for the self participates in their representation, is transported by the "rhythm" that charges them. To be so engrossed in a story as to forget the pen that wrote, the space, and people around you, are the effects of "rhythm" which Levinas is problematising. "Rhythm" is not to be understood as a property of the temporal and plastic arts. "Rhythm" as musicality is the sway the poetic order as image (which need not be static or visual although activated by the imagination) has on us. "Rhythm" in this widened sense becomes the intensification of the effect of the image on the "I": it captivates and holds the self within its thrall. It is in this sense that Levinas says «the whole of the world can touch us musically, can become an image» ${ }^{26}$, pressing two aspects of the same relation in what is only superficially an oxymoron.

\footnotetext{
${ }^{24}$ Ivi, p. 134.

${ }^{25}$ E. Levinas, Totality and Infinity, cit., p. 198.

${ }^{26}$ E. Levinas, Reality and its Shadow, cit., p. 134.
} 
The danger of "rhythm" in relation to ethics pivots on the role of "sensation". "Sensation" is the "neutralisation" of the object as reality, and belongs to an altogether different ontological category of non-truth. Although in Totality and Infinity "sensation" will come to equate the "middle-term" by which the "I" makes sense of the world through concepts and theory ${ }^{27}$, in Reality and its Shadow "sensation" is a cognitive passivity. To sense is to do otherwise than to possess and therefore suspend an alien world; suspension requires the comprehension of an object by conceptualising it or representing it, which presupposes the ability to possess alterity by its integration within the "I". In sensation we cannot speak of possession, but of a passivity that does not lend itself to the active powers of comprehension. And because the sensible permeates cognition, it is not difficult to see why for Levinas rhetoric as a mode of discourse was for instance deeply unethical, reliant as it is on figures of speech, imagery and rhetoric devices whose persuasive import pivots on sensation, where words as symbols become images.

Here we should clarify the subtle difference between representation and sensation as it figures in RS. To represent requires comprehension, which is its self an interpretation, and representations are themselves interpretable. The artist produces a representation which then urges further interpretation, further criticism. But because the act of representation is the production of an image and not a concept offering itself to discourse (conceptual art is no exception), representation as sensation can trap the "I" in its "rhythm". To interpret sensation is to recover from the state of absorption it engenders by appealing to conceptualisation. So, although representation too can be conceptualised (and this would be the role of criticism which reintegrates art into discourse, into ethics), it is also "image", whose quality appeals most strongly to the faculty of sensation. Herein lies the danger for Levinas.

These two modes of relating then, to sense and to neutralise, or to possess and suspend, seem to run parallel to one another and to compete for attention. But if representation requires comprehension, which is the ability of the "I" to make use of its powers, and sensation is the faculty upon which it rests, why is the aspect of sensation in the work of art denounced more vigorously than sensation in conceptualisation? Simply because if art's most basic operation is that of the substitution of the object for

\footnotetext{
${ }^{27}$ E. Levinas, Totality and Infinity, cit., p. 142.
} 
its image, then sensation enjoys a central role in art, seeing that the primary way of relating with an art work is aesthetically, etymologically speaking, through the senses ${ }^{28}$. The danger with art then, is a way of relating to the world that begins and stops with sensation, strengthened by the "rhythm" the work of art engenders.

\section{2.i. Rhythm and I}

From the standpoint of phenomenological analysis, the effects of "rhythm" upon sensation sever art from ethics altogether. That our cognitive reality should be contiguous with our ethical reality, or rather closer to it, lies in the fact that in grasping an object we retain our egoic identity, the necessary counterpart for the irruption of the "other" in us. Participation through "rhythm" on the other hand, forestalls the powers of the "I" to comprehend. This induces a descent into "anonymity". We can think of this state as a "captivation", "absorption", and "ecstasy" [ékstasis: standing outside oneself], characteristic for instance of orgiastic rites or anecdotes of communion with the divine, where the "I", «stripped of its prerogative to assume»" ${ }^{29}$, is no longer able to freely exercise its power to conceive and grasp. The power of the "I" is reversed into participation whereby the "I" is now «among things as a thing»" Although the irruption of "other" also interrupts the free exercises of our power by exceeding them and «calling them into question» ${ }^{31}$ it is unlike this relation in that it frustrates the ethical component: where there is no "I", there is no one that can desire, witness and learn; when there is no "I", the "other" cannot express, reveal or teach. The "I" goes from an affirmative "I can" to an anonymous absorption into play.

Yet if there is no "I" that is transfixed in "rhythm" but only an anonymous entity, can we still speak of enjoyment derived from art? Or is this simply the consequence of participation? And if the state of anonymity is fully possible, what is it that rescues identity? Lastly, can participation be properly called an injustice if there is no "I" to

\footnotetext{
28 These distinctions are artificial and based on a history of aesthetics, and more fundamentally a history of a metaphysics, that has progressed (and at times regressed) by way of analysis in order to understand complex phenomena. The idea that you can discriminate between "faculties", such as intellectual and sensory, and treat them as separate modalities of cognition is a deep-seated bias in Western thought. Still, we should remind ourselves that Levinas's is not a theory of perception, and that his qualms are with the ethical irresponsibility art can engender. For the sake of argument, I proceed under the prescribed limits.

${ }^{29}$ E. Levinas, Reality and its Shadow, cit., p. 133.

${ }^{30}$ Ibid.

${ }^{31}$ E. Levinas, Totality and Infinity, cit., p. 196.
} 
answer? Recalling what Levinas says about identification in Totality and Infinity helps us answer these questions. The state of anonymity is already a calling for identity: «the I is not a being that always remains the same, but is the being whose existing consists in identifying itself, in recovering its identity throughout all that happens to it. It is the primal identity, the primordial work of identification $\gg{ }^{32}$. From this it follows that even anonymity is but a variation of the "I". For even though participation in "rhythm" is not an encounter with alterity from which the "I" recovers itself, it is an alteration of the "I"'s self-consciousness which only temporarily inhibits its capacity for identification. The "I" recovers itself for it was never annihilated. And because we cannot properly speak of freedom in a state of anonymity, we cannot speak of responsibility either. Nonetheless, if the "I" is only but temporarily displaced from its powers and hence freedom, we can still speak of injustice in anonymity, since it is not the "other" that provokes its displacement but a play of the same.

The play of the same by the "I", which is its tendency to totalise, can be broken only when «thought finds itself faced with an other refractory to categories» ${ }^{33}$. The capacity for thought plays a pivotal role in the ethical encounter: for only through thought can the Levinasian "other" contest the totalising powers of the "I", its spontaneous freedom, and therefore overflow the idea of "infinity" within the "I". This irruption is also what for Levinas means to be taught. In art as we have seen it, the "I" is transported by the "rhythm" of the image along a stream of sensation, in which the "I", becoming anonymous, neglects its capacity for critical thought. Participation in "rhythm" as anonymity in sensation clouds orientation toward the "other". From the state of anonymity, we can draw no positive ethical value in Levinas's terms.

\section{The ethical value of art in virtue of its inhumanity}

We have seen that this notion of art does not lend itself to the ethical relation. To show this, we had to understand what it means for art to be "inhuman" and an "inversion" of ethics. We also brought in the notion of the "other" to see how the simple enjoyment of art is fundamentally irresponsible because it removes from alterity the power to

\footnotetext{
${ }^{32}$ Ivi, p. 36

${ }^{33}$ Ivi, p. 40.
} 
interrupt the totalising impulses of the "I". In art the "other" cannot speak, for even if the "other" is undefinable, so that we could think of the "face" metaphorically, art lacks a "face" nonetheless since severed from being; even those arts that reincorporate the authenticity of the "face" by using the living body as their materia prima fail to call into question the totalising impulses of the "I" in virtue of their artistic completeness and self-sufficiency ${ }^{34}$. Being is substituted by its image and trapped in the time of the "meanwhile" which it cannot traverse nor contest. Nor can art be a conduit to the ethical relation through language for in art language ceases to be frank expression and doubles up reality through representation. Lastly, art cannot be a mirror with which to encounter the "other" in "self", for the model of the Levinasian "I" is incapable of "apostasy" with regards to its own alterity: the "I" is incapable of abandoning its own identity since it is constantly trying to recover it. Seeing all this, must art only be read as irresponsible "inhumanity" and an "inversion" of ethics? Or can art as "inhumanity" and as "inversion" have its positive value, and not just for the work of criticism? To answer this question, we must look further into the «perspective of the relation with the other» ${ }^{35}$.

In Totality and Infinity Levinas seeks to establish the primacy of the "other" over the self or "I": the primacy of ethics over ontology. His philosophy is as much a description of the ethical relation as it is a criticism of Western thought. Ontology, as the comprehension of Being, promotes freedom of the self, allows the "I" to not be alienated by the "other". In reaction to Heidegger's ontology Levinas urges that to «affirm the priority of Being over existents [...] subordinates justice over freedom» ${ }^{36}$. The ethical relation is thus the source of intelligibility, for only the "other" can call into question the totalizing exercise of the same. Only the "other" can properly teach the "I", for it is the "other" that introduces novelty into the sphere of the "I" by exposing it to what it cannot grasp, cannot comprehend, cannot reduce to concepts. The relation of "I" toward the "other" is therefore both hostile and desirous. It is hostile when the impulse toward comprehension, toward knowledge, reduces alterity to a middle and neutral term

\footnotetext{
${ }^{34}$ There is much more to be said here, for this might be a viable way to reinstate ethics in art by leveraging nuances in the primordial work of identification, the time of the "meanwhile" and the constituted time of the artwork. It is possible that the encounter with the "other" take place within the constituted time of the work of art even though its completeness helps represent the encounter to the self and therefore suspend alterity.

${ }^{35}$ E. Levinas, Reality and its Shadow, cit., p. 142.

${ }^{36}$ E. Levinas, Totality and Infinity, cit., p. 45.
} 
called "concept" or "being", consequences of what Levinas sees as a totalising exercise of the same ${ }^{37}$. And it is desirous insofar as it lives from «the marvel of exteriority» ${ }^{38}$. It lives from the desire of what it cannot comprehend, a desire which is not born from lack but from abundance, and so cannot be fulfilled: «desire is the need of him who has no more needs» ${ }^{39}$. The "I" is drawn almost as if by compulsion toward what is properly invisible, toward "infinity": drawn by a "metaphysical desire" which founds every-day "sociality". Yet the experience of "infinity", whose seat is the "face to face" relation, is also shocking. The "other" floods the concept of "infinity" of the "I" and so fundamentally pre-empts its attempts to grasp, to comprehend. Herein lies the shock. It is in this ambivalent relation - at once hostile and desirous - that the term "allergy" is used to qualify the movement of the "I" toward the "other". Metaphysical desire is described as the "non-allergic" relation with the "other", apperceived in discourse. Comprehension, or the grasping of the "other", as the "allergic" relation. We read: «to know amounts to grasping being out nothingness, or reducing it to nothing, removing it from its alterity» ${ }^{40}$. This is at once Levinas's criticism of ontology: «the relation with Being that is enacted as ontology, consists in neutralising the existent in order to comprehend or grasp it. A [...] reduction of the other to the same» ${ }^{41}$. It is to «maintain the self against the other», to affirm the «autarchy of the I» ${ }^{42}$. For Levinas, "concepts" as mediators, are of value only if they do not neglect the infinite distance separating an existent from another. This insurmountable distance is the source of ethics as epitomised in language, where language as discourse attempts to at once move across and maintain this very distance. In this case, the concept thought, needed for discourse, still respects the alterity of the "other". On the other hand, to make the concept, or representation, coincide with the "other" is a form of negation. Negation, through domination, labour, work, comprehension etc., is a «power by essence murderous of the other» ${ }^{43}$. "Murderous" because in removing the "other" from its alterity, the "I" is essentially reducing the "other" to a concept it can grasp, such as Being, a general third

\footnotetext{
${ }^{37}$ Ivi, p. 46.

${ }^{38}$ Ivi, p. 42.

${ }^{39}$ E. Levinas, The Trace of the Other (1963), transl. by A. Lingis, in M. Taylor (ed. by) Deconstruction in context: literature and philosophy, University of Chicago Press, Chicago 1998, p. 350.

${ }^{40}$ E. Levinas, Totality and Infinity, cit., p. 44.

${ }^{41}$ Ivi, p. 45.

42 Ibid.

${ }^{43}$ Ivi, p. 47.
} 
term which although corresponds with the particularity of the "existent" it is not the existent. Discourse, by contrast, reflects an openness toward alterity: it is the apperception of one's "metaphysical desire" for the "other", a "non-allergic" relation to alterity, where the "I" is faced with the impossibility of "murder", for in discourse, the totalising power of the "I" is called into question. The "I" continuously oscillates between these two modes, given that in discourse the "I"'s ability to comprehend is simultaneously required and called into question. It follows then, that the logical extreme of the "I"s totalizing powers is actual murder. «To kill is not to dominate but annihilate; it is to renounce comprehension absolutely» ${ }^{44}$. When comprehension is renounced, the "infinity" of the "other" cannot flood the concept of infinity in the "I". When comprehension is renounced, the "other" cannot contest the power of comprehension of the "I".

And so, we return to our question: can art as "inhumanity" and as "inversion" have its positive value, and not just for the work of criticism and philosophy? From the issue with art we recall: art «consists in substituting for the object its image» ${ }^{45}$; the image traps the object on the "hither side of time", the "meanwhile", and precludes it from its ability to "speak". Further, as we've seen in the second section, the sway of "rhythm" in art is such that in sensation the "I" participates in an anonymous absorption into play, and so renounces its power for comprehension. This mode of being is irresponsible for it pre-empts the ability of the "other" to call the very power of the "I" into question. To this however, we must nuance two points. Firstly, in the case of art, comprehension is renounced not "absolutely" but relatively, since it is directed toward the image of the existent and not the existent itself. Secondly, the power of the "I", by essence murderous of the "other", cannot be exercised in participation. In "rhythm" the "I" is «stripped of its prerogative to assume»" ${ }^{46}$. In anonymity the "I" suspends not only its ability to comprehend alterity, but also its ability to comprehend itself as an "I". Yet comprehension is renounced temporarily, for only in this way can the work of identification recover the "I" from anonymity. The "I" directs its murderous impulse towards alterity which it turns to images, and then renounces this impulse by participating in these very images. In this relative and temporary renunciation of power,

\footnotetext{
${ }^{44}$ Ivi, p. 198.

${ }^{45}$ E. Levinas, Reality and its Shadow, cit., p. 132.

${ }^{46}$ Ivi, p. 133.
} 
the "I" explores its suicidal as well as murderous aspects by participating in the very operation of art as a thing amongst things ${ }^{47}$. The distance the "I" cannot traverse in his relation with the "other" is traversed in "rhythm" by its participation in "images". Under the above reading, art is a controlled and studied means of negation, that concedes to alterity its power to interrupt yet resists it by denying it from the "image" and itself. In the image alterity has no power, but neither does the "I" in participation with the image.

We recall that sensation is «a mode of depriving the known being of its alterity» ${ }^{48}$ in which «the shock of the encounter of the same with the other is deadened» ${ }^{49}$. And further that the primary way of relating to art is aesthetically, etymologically speaking, through the senses. That humanity should have availed itself of art then, may attest not only to the «insecurity of a being which has the presentiment of fate $»^{50}$, but more acutely to the need of coping with the shock of alterity. «The epiphany of the face brings forth the possibility of gauging the infinity of the temptation to murder, not only as a temptation to total destruction, but also as the purely ethical impossibility of this temptation and attempt» ${ }^{51}$. In art, the tempted finger pulls the trigger; desiring, it averts the target and aims its semblance. The "I" responds to the alienating shock of the "other", annihilating as it were, the image, the double of being and not the being itself, and participating in this same annihilation. Art as a quasi-murder that «exercises a power over what escapes power» ${ }^{52}$, namely death (which is opposed by giving artworks constituted durations) and the "other", which is opposed by substituting it for the image of its representation. It is in art's most basic operation then, that we can find the "nonallergic" integration of the "allergy" toward the "other". "Allergic" because beings are represented, "non-allergic" because it is only their shadows that are trapped in their fate and temporarily annihilated. Art as "inhumanity" and "inversion" of ethics finds its positive ethical value in this subsumption. The subsequent participation in "rhythm" reveals the need of ritualising the tension between an overpowering metaphysical desire and the desire to overpower what is beyond our power. Ethics cannot be subordinated to art, but nor can art be marginalised to enjoyment; this would trivialize the latent

\footnotetext{
${ }^{47}$ Ibid.

${ }^{48}$ E. Levinas, Totality and Infinity, cit., p. 42.

${ }^{49}$ Ibid.

${ }^{50}$ E. Levinas, Reality and its Shadow, cit., p. 140.

${ }_{52}^{51}$ E. Levinas, Totality and Infinity, cit., p. 199.

${ }^{52}$ Ibid., p. 198.
} 
murderous temptation of the "I", which in art finds expression as a failure to reconcile it with "desire". This failure is the production of and participation in "image".

\section{Conclusion}

To conclude, art cannot come to replace the ethical relation for Levinas, and criticism is necessary for its reintegration within the ethical sphere. However, it cannot be marginalised to a mere source of pleasure or enjoyment for this would be the trivialisation of the lesser extreme of our murderous tendencies. Applying his mature work to his criticism of art, offers insights that pivot on the "I's" need to reconcile its "metaphysical desire" with its "murderous tendencies".

In art's most basic operation, the substitution of the object for its image, we see the failure to reconcile the murderous and desirous movements of the "I" toward the "other". It is an "I must" rather than an "I can". The impotence inflicted on the "image" to fulfil a life beyond the interval of the "meanwhile" is its poignant potence, offering the self a temporary release from anxiety over death, and a simultaneous enactment of its murderous impulse. The "I" renounces comprehension of the "image" of being, conceding its "allergic" movement toward alterity, and participates in its sensible qualities of the "image" so as to leave the original unscathed, thereby recognising its "non-allergic" pull toward the "other". Art as "inhumanity" and "inversion" of ethics finds its positive ethical value in this subsumption. 